\title{
Residence time and physical processes in lakes
}

\author{
Walter AMBROSETTI*, Luigi BARBANTI and Nicoletta SALA ${ }^{1)}$ \\ CNR Institute of Ecosystem Study, L.go V. Tonolli 50, 28922 Verbania Pallanza, Italy \\ ${ }^{1)}$ University of Italian Switzerland- Academy of Architecture, Mendrisio (TI) \\ *e-mail corresponding author: w.ambrosetti@ise.cnr.it
}

\begin{abstract}
The residence time of a lake is highly dependent on internal physical processes in the water mass conditioning its hydrodynamics; early attempts to evaluate this physical parameter emphasize the complexity of the problem, which depends on very different natural phenomena with widespread synergies. The aim of this study is to analyse the agents involved in these processes and arrive at a more realistic definition of water residence time which takes account of these agents, and how they influence internal hydrodynamics. With particular reference to temperate lakes, the following characteristics are analysed: 1) the set of the lake's caloric components which, along with summer heating, determine the stabilizing effect of the surface layers, and the consequent thermal stratification, as well as the winter destabilizing effect; 2) the wind force, which transfers part of its momentum to the water mass, generating a complex of movements (turbulence, waves, currents) with the production of active kinetic energy; 3) the water flowing into the lake from the tributaries, and flowing out through the outflow, from the standpoint of hydrology and of the kinetic effect generated by the introduction of these water masses into the lake. These factors were studied in the context of the general geographical properties of the lake basin and the watershed (latitude, longitude, morphology), also taking account of the local and regional climatic situation. Also analysed is the impact of ongoing climatic change on the renewal of the lake water, which is currently changing the equilibrium between lake and atmosphere, river and lake, and relationships
\end{abstract}

Key words: Residence time, vertical mixing, heat content, wind, hydrology, model

\section{INTRODUCTION}

The evaluation of the mean residence time of water in a lake is a problem of fundamental importance for theoretical and applied limnology. Only such an evaluation in real terms can lead to a knowledge of, for example, the proportions and dynamics of the chemical substances dissolved in the water, or the rate at which the processes of concentration, dilution and permanence of substances within the lake occur, with resulting implications for the water quality.

Leaving aside the relations between nutritional salts and the biological productivity of the water, and thus also the retroaction of productivity on the chemical budget of a lake, it is clear that mean residence time is what controls the concentrations and accumulative capacity of all the substances entering a lake basin, whether naturally or artificially. The chemical evolution of a lake can be predicted only if this parameter is known, in relation to its current or future load. It is more urgent than ever to find a solution to such problems, with limnologists now responsible for defining the chemical state and the trophic level of individual lakes, their self-purifying capacity, and the degree of acceptability to which they must conform, so that legislators and technicians can intervene in whatever way is necessary to safeguard the immense wealth of freshwater contained in our lakes.

\section{FROM THEORETICAL TO REAL RENEWAL TIME}

Researchers once used to refer to the so-called "theoretical renewal time" of lake water, calculated from the ratio between the volume of the lake and the volume of its outflow; this might be regarded as the first step towards a real evaluation of renewal time. This hypothesis, however, works on the assumption that the lake is formed like a stretch of river, with a wide section, and with very regular morphometry, within which the water is conveyed more or less uniformly (laminar flow) and without that complex of physical phenomena which plays such an important part in the annual cycle of lakes, such as thermal stratification, for example. This is obviously a rather unsophisticated approach to the problem, but nevertheless gives an idea of the hydrological vivacity of a lake. Vollenweider (1975) makes good use of the approach in his models of the trophic classification of lakes.

Table 1 shows the theoretical renewal times of the water in the main Italian lakes: the times depend largely on the morphometric characteristics of the individual basins and of their respective watersheds, and on the volume of precipitation over the whole area. However simplistic it may be, the theoretical time shows a very marked variability between the values due to the differences in the morphological characteristics of the lakes and their watersheds, and their location in areas with different hydro-meteorological situations, precipitation 
Tab. 1. Morphometric and hydrological characteristics of the largest Italian lakes.

\begin{tabular}{|c|c|c|c|c|c|c|c|c|c|c|c|}
\hline & $\begin{array}{l}\text { Lake area } \\
\qquad\left(\mathrm{km}^{2}\right)\end{array}$ & $\begin{array}{c}\text { Max depth } \\
\text { (m) }\end{array}$ & h Mean depth & $\begin{array}{l}\text { Volume } \\
\left(10^{9} \mathrm{~m}^{3}\right)\end{array}$ & $\begin{array}{c}\text { Drainage } \\
\text { basin area } \\
\left(\mathrm{km}^{2}\right)\end{array}$ & $\begin{array}{c}\text { Mean out. } \\
\text { discharge } \\
\left(\mathrm{m}^{3} \mathrm{~s}^{-1}\right)\end{array}$ & $\begin{array}{c}\text { Precipitation } \\
(\mathrm{mm})\end{array}$ & $\begin{array}{l}\text { Lake } \\
\text { outflow } \\
(\mathrm{mm})\end{array}$ & $\begin{array}{l}\text { Outflow } \\
\text { coefficient }\end{array}$ & $\begin{array}{c}\text { Theoretical } \\
\text { ret. time } \\
\text { (years) }\end{array}$ & $\begin{array}{l}\text { Lake area/ } \\
\text { basin area }\end{array}$ \\
\hline Garda & 367.9 & 350 & 133.3 & 49.03 & 2260 & 59.5 & 1199 & 799 & 0.67 & 26.8 & 6.1 \\
\hline Maggiore & 212.5 & 370 & 177 & 37.1 & 6599 & 297 & 1703 & 1420 & 0.83 & 4 & 31.1 \\
\hline Como & 145.9 & 410 & 154 & 22.5 & 4572 & 158 & 1295 & 1091 & 0.84 & 4.5 & 31.3 \\
\hline Trasimeno & 124.3 & 6 & 4 & 0.59 & 376 & 0.86 & 837 & 72 & 0.09 & 21.6 & 3 \\
\hline Bolsena & 113.6 & 151 & 81 & 9.2 & 273 & 2.42 & 980 & 280 & 0.29 & 120.6 & 2.4 \\
\hline Iseo & 60.9 & 258 & 124 & 7.55 & 1842 & 59.4 & 1220 & 1018 & 0.83 & 4.1 & 30.2 \\
\hline Bracciano & 57.0 & 164 & 88.6 & 5.05 & 147 & 1.17 & 1122 & 251 & 0.22 & 137 & 2.6 \\
\hline Lugano & 48.9 & 288 & 134 & 5.86 & 615 & 25 & 1676 & 1283 & 0.77 & 8.3 & 12.6 \\
\hline Orta & 18.1 & 143 & 69.4 & 1.25 & 116 & 4.64 & 1825 & 1262 & 0.69 & 8.9 & 6.4 \\
\hline Varese & 14.9 & 26 & 11 & 0.16 & 110 & 2.87 & 1454 & 823 & 0.57 & 1.7 & 7.4 \\
\hline Vico & 12.1 & 48.5 & 21.5 & 0.26 & 41 & 0.49 & 1316 & 377 & 0.29 & 17 & 3.4 \\
\hline
\end{tabular}

in particular. The geographical distribution of Italian lakes is a determining factor. Those in the subalpine area are mostly shaped by glacial tongues during the last cold periods and now fed by watercourses flowing down from the Alps, have relatively short renewal times. Garda, the largest Italian lake in area and volume, is to some extent an exception, because of the very large mass of water in its basin $\left(50 \mathrm{~km}^{3}\right)$ and the relatively low volume of its outflow. The lakes of Central Italy, the volcanic lakes and Lake Trasimeno, have a much lower hydrological vivacity, largely because of the low ratio between the areas of the watersheds and those of the lakes.

But, as is well known, lakes during their annual cycle develop differentiated vertical thermal structures which, according to their geographical, climatic and morphological conditions, result in one or more periods of vertical thermal stratification during which the thickness of the layer involved in the water renewal, i.e. the layer mixed at the surface, represents only a more or less important percentage of the whole water mass. Of the other factors that condition the river-lake-river hydrological complex, the most important are the current system and the other movements arising in the lake, the topography of the bottom, and the morphology of the basin, which is very often highly irregular due to the presence of bays or lateral arms, only to some extent affected by the general dynamics of the lake. Clearly there was a requirement to formulate more realistic water renewal times, and this is the direction recent research has taken.

The first approaches were both experimental and theoretical: the experimental approach assumes a detailed knowledge not only of the hydrological characteristics of the river-lake system, but also of the physical (thermal and dynamic) parameters present in the lake, as well as the changes these undergo in the course of the annual cycle. All this serves to define with reasonable accuracy the volumes of water involved in the renewal. The theoretical approach, on the other hand, consists in devising models which can translate into mathematical language the thermal and dynamic phenomena observed.
Of the experimental solutions, the best-known Italian attempt is that proposed for Lago Maggiore by Tonolli (Piontelli \& Tonolli 1964), which allows as a simplifying hypothesis that the "exit of water via the outflow occurs indifferently within the whole thickness of the layers which reach the same temperature as the surface waters during the seasonal cycle". After analysing the annual and pluriannual thermal cycles of the lake water, Tonolli reached the conclusion that the mean residence time of water in Lago Maggiore was around 14.5 years, contrasting with the 4 theoretical years.

Another example of an experimental study is that performed by Kajosaari (1966) on the system of Lake Rouversi (Finland), which comprises 4 interconnecting basins. To evaluate the residence time of the water in this complex, the author used as a tracer an industrial effluent containing a high sulphite concentration.

Mathematical models devised for some Italian lakes include Biffi's (1963), Piontelli's (Piontelli \& Tonolli 1964) and Vollenweider's (1964); they all share the hypothesis that the quantity of substances present in lake water is a function of the input, consumption and loss of those substances. This hypothesis is expressed in the three models with different parameters: for Biffi, the essential factor is exclusively the hydrology of the riverlake system; Piontelli also takes account of the dependence of the water chemistry on sediment exchange; Vollenweider introduces the idea of a possible chemical reaction in the water mass. Rainey's (1967) conclusions are also interesting: he applied to the American-Canadian Great Lakes of the St Lawrence system a mathematical model based exclusively on hydrological considerations.

Vollenweider (1969) takes up Tonolli's observations on the thermal characteristics of Lago Maggiore, and with the intention of integrating their variations over time into a more complete mathematical formula suggests that the concept of "effective outflow" should be added to that of "theoretic outflow", expressed by a coefficient equal in size to the inverse of time. To calculate this the volume of the "mean epilimnion" must be known, i.e. the volume of water which over the year can be renewed by virtue of its thermal homogeneity. 
The overall picture emerging from these initial approaches is thus already extremely complex, with a variety of phenomena and with widespread synergies, such as processes of thermal stratification and destratification of lake waters, their vertical mixing in late winter, and the circulation triggered by the inflow from the tributaries. Each of these must be evaluated on the basis of the amount of energy required to set off the phenomena and subsequently to dissipate them. There is therefore a complex set of problems, involving the interaction between lake and surrounding environment, and especially the exchanges of caloric, mechanical and mass energy with the atmosphere and the watershed.

Essentially, these early approaches underlined the complexity of the phenomenon and pointed to the need for increasingly detailed information on lake hydrodynamics, also as an indispensable prerequisite for determining the real residence time of water in each basin. Also Weiss et al. (1991) maintain that one of the requisites for understanding how a lake ecosystem functions physically, chemically and biologically is its rate of deep water renewal by exchange with surface waters (the so-called "ventilation" process). This exchange controls the internal distribution of water properties, so controlling the time dependent response of the lake to its own chemical and biological processes, as well as to natural and anthropogenic external disturbances. Physical limnologists have in recent decades devoted much energy to studying the mechanisms of vertical mixing of lake water, even independently of the question of its renewal time. In this sense modern physical limnologists are trying on the one hand to extend knowledge of their own discipline, while on the other they are participating with increasing authority in interdisciplinary studies of the most complex of the processes occurring in the lake ecosystem, including the process involved in water renewal time.

A further step will involve research leading to a descriptive model by analysing those already in use, a model which will take account of other parameters in addition to those mentioned above; though a model which fits all lakes is not a practicable proposition, due to the differences in their geology, morphology and climate. For instance, two lakes like Bolsena and Maggiore exhibit wide differences, such as the ratio between the areas of the lakes and their watersheds, their different climatic conditions (precipitation, solar radiation, wind etc.), the shape of the basin (round in Bolsena, elongated in Maggiore), exposure to wind leading to different sinking of the thermocline in summer, influence of tributaries, crossing flows and the systems of currents and seiches which are more pronounced in Bolsena. What emerges from these profiles is that in Bolsena the most important factor is heating, in a broad sense, while in Maggiore the hydrological situation is dominant.
Carmack et al. (1986) analysed the seasonality of a deep temperate lake (Lake Kootenay, British Columbia), trying to highlight the mechanisms affecting the circulation and distribution of the water mass and subdividing their observation into six periods. Knowledge of these mechanisms helped to understand the spacetime variability which makes it possible to evaluate water renewal time, and also assists our understanding of the behaviour of that lake and its associated ecosystem. Other studies, especially those dealing with lakes with a long residence time, took account of variables such as wind and local heat exchange (Sundaram \& Rehm 1973; Mortimer 1974; Holland \& Simmons 1978). Other studies used numerical models for lakes and basins (Tucker \& Green 1977; Imberger et al. 1984).

Some very recent studies involve determining renewal time using numerical 3D modelling (Rueda 2001). Rueda describes experiments and measurements performed on Little Sodus Bay, one of the seven bays considered in his study. The numerical experiments consisted in measuring a tracer (of mass $\mathrm{m}_{\mathrm{o}}$, expressed in $\mathrm{kg}$ ) in a given position and simulating the evolution of the tracer over time. Mean residence time was calculated using the equation:

$$
\tau_{\gamma}=\frac{1}{m_{0}} \int_{0}^{\infty} \frac{d m}{d t} t d t=\frac{1}{m_{0}} \int_{0}^{\infty} m(t) d t
$$

Simulations continued for five months, performed with a precise system for lake hydrodynamic phenomena which takes account of chaotic and turbulent flow, and in particular allows the use of Navier-Stokes equations and incorporates a form of Mellor-Yamada scheme for turbulent systems (Smith 1997; Rueda 2001; Rueda et al. 2002).

\section{FORCES RESPONSIBLE FOR LAKE HYDRODYNAMICS}

If we are to define realistic water renewal times, we need a complete picture of the hydrodynamic processes occurring in the lake, themselves conditioned by the morphology of the territory, and we must identify the agents which drive them. With particular reference to temperate lakes, Ambrosetti \& Barbanti (1988) summarised the forces as follows:

a) the set of the lake's caloric components, which, along with the summer heating, give rise to the stabilising effect of the surface layers and the consequent thermal stratification, as well as the winter destabilising effect (de-stratification) triggered when the lake's heat budget becomes negative;

b) the force of the wind, which transfers part of its momentum to the water mass, giving rise on the surface and in the deep layers to a complex of movements (waves, currents, seiches) with the active production of kinetic energy; 
c) water flowing into the lake via the tributaries, and out of the lake via the outflow, considered not only from a hydrological point of view, i.e. as the addition of a quantity of water, but also from the point of view of the kinetic effects triggered by their entering the lake.

This kind of subdivision of the forces responsible for lake hydrodynamics has purely schematic value, as in reality the individual processes interact, often in contrast with each other. For instance, the formation of the upper mixed layer is merely the combined effect of floating following the heating of the superficial layers, and the water movements triggered by the wind which tend to convey the heat to deeper waters. However, the fact that the action of the various external forces is often contemporaneous and synergic should not preclude an analysis of each one, as, taken together, they have the major responsibility for lake hydrodynamics.

A striking study of the contemporaneous action of different external agents, their complex synergies, and the differing responses of waterbodies was conducted by Wuest et al. (1988) on the Lake Lucerne (CH). The two adjoining basins which compose the lake, the Gersawersee and the Urnersee, similar in size and depth, separated by a sill of $85 \mathrm{~m}$ depth, and located in the same macroclimatic zone, nevertheless have other physical characteristics which are not entirely similar, especially a very different exposure to the wind and to tributary input, with the result that their response to the external physical forces are very different. The exposure of the Urnersee to the wind, the greater volume of water flowing into the basin, and a dissimilar water chemistry due to a different concentration of dissolved chemical substances mean that there is a faster renewal rate in the hypolimnion. In particular, the wind's action is strong in winter and spring, while the density currents induced by the tributaries and by the lateral water exchange are active in summer, and are the chief cause of the different hydrodynamic behaviour of the two basins.

\subsection{Heat budget, stratification and de-stratification}

The heat budget of a lake represents in synthesis the annual exchange of heat with the surrounding environment (essentially the atmosphere), and also provides a picture of the specific incidence of individual components on the lake's hydrodynamics through their quantitative evaluation.

Many variables are involved in exchange mechanisms, starting with the primary energy source of the sun, in addition to the physical characteristics of the two contiguous mediums and the fundamental elements of atmospheric dynamics in relation to those of the water mass. All these elements are obviously conditioned by the general geographical characteristics of the lake basin and its watershed (latitude, altitude, morphology), and by the local and regional climate. Of the individual components of the heat budget of a lake, those which are quantitatively most important are incident and reflected solar radiation, net long-wave radiation, sensible and evaporation heat, net advected energy, and lastly the heat stored in or lost from the lake.

\subsubsection{Heating phase}

The turbulent motion regime determined by the action of the wind on the lake surface transports heat to the deep layers by displacing the surface water, which is warmer and lighter as a result of solar radiation, to the depth at which the turbulent motions succeed in overcoming the resistance of the "bouyancy force" due to the difference in density between the layers.

Here some clarification is required, which is not merely terminological: as Wuest et al. (1988) point out, water exchange and mixing are two separate processes responsible for the transport of water and its dissolved or suspended constituents. In exchange, the water volumes change their position but retain their chemicalphysical identity. In mixing, homogenisation occurs, with the amalgamation of water particles and the formation of another type of water, with new characteristics. Of course, the distinction between "exchange" and "mixing" is in a sense an artificial one, because there can be no exchange without mixing (at least not at the boundaries of the water masses involved in the exchange), and also because it is a question of time- and length-scale if the water movement is to be regarded as exchange or mixing.

In early spring the transport of heat to the deep layers produces in the lake a characteristic thermal structure which, at least in the commonly accepted classic three-layer stratification model, comprises an epilimnion at the surface, a metalimnion which is the intermediate layer, and a hypolimnion at the bottom. "Thermocline" is the term used to refer to the level of maximum vertical heat gradient in the metalimnion.

The definition of these thermal structures is conditioned by the morphometric characteristics of the lake. Studies on the control exerted by morphometry on lake dynamics, in this case on the summer thermal stratification, allowed us (Pompilio et al. 1996), using data from 30 Italian lakes and a predictive mathematical model, to show that potential fetch, i.e. the distance over which a wind can blow without encountering natural obstacles, is the best indicator of the depth at which the thermocline will be established in a lake. However, we also found significant differences of behaviour, especially between circular and elongated lakes. Furthermore, lakes in Italy and other lakes in different parts of the world were compared to evaluate the influence of the local climate on heat stratification, particularly through solar radiation (essentially determined by the latitude of the lakes) and wind regime. A distinction also emerged between the thermal behaviour of lakes regarded as climatically "continental" and "oceanic". 


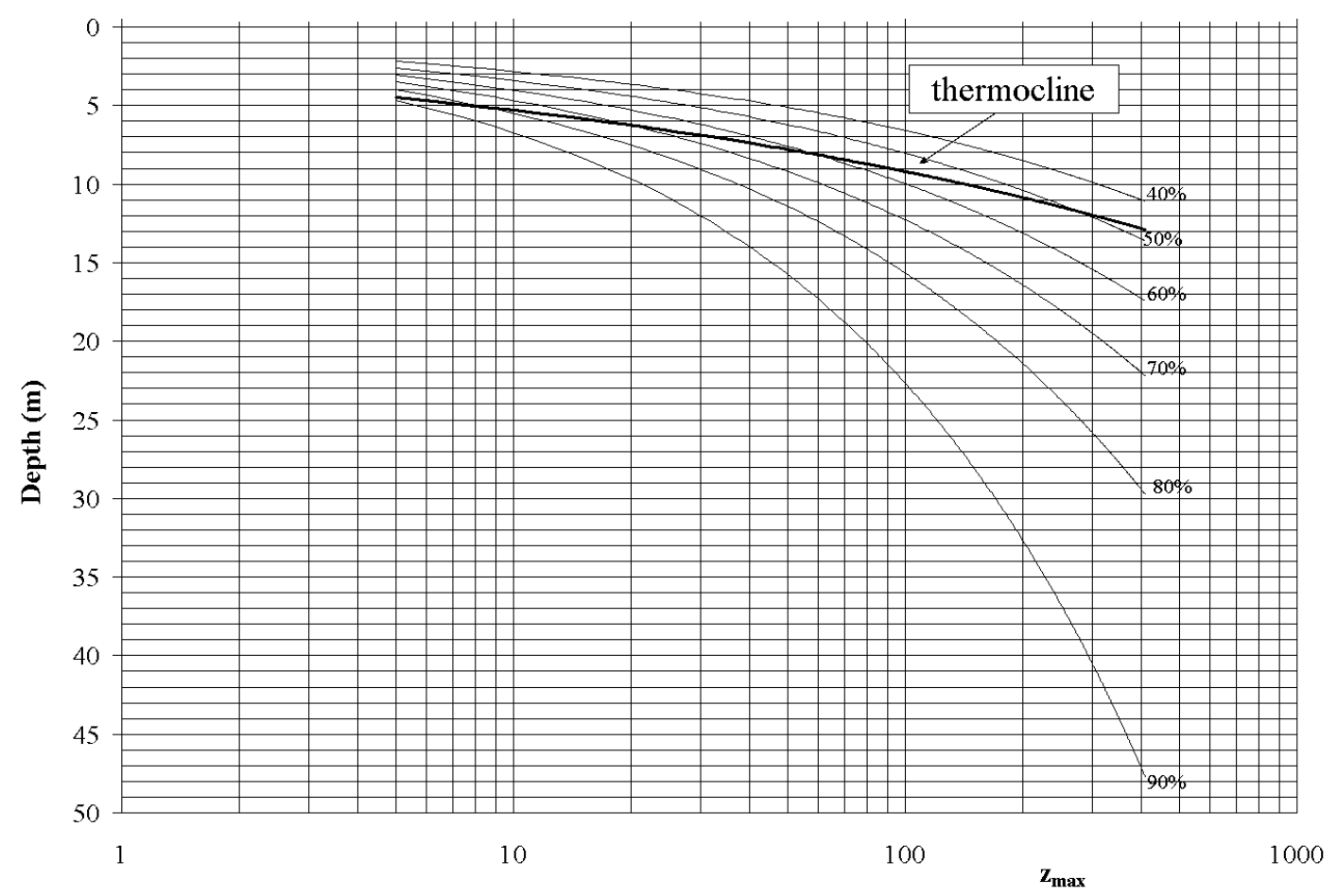

Fig. 1. Depth of percentages of annual heat exchange and depth of thermocline for the period July-August in 31 Italian lakes.

Barbanti et al. (1996) used an application of this model to predict the type of summer stratification, or the possible establishment in the lake of systems of one, two or three layers, thanks to a simple index, calculated as the ratio between the depth of the epilimnion, predicted on the basis of the lake's morphometric characteristics, and the maximum depth of the lake. This prediction can be extended to the whole annual thermal cycle, so following the warming and cooling phases of the lake.

In addition, the 30 Italian lakes considered were divided into three groups: those which are almost permanently homeothermic or intermittently stratified during calm periods, those which develop a two-layer system, and lastly a group of holo-oligomictic lakes which have a three-layer system.

Still in the context of research performed to clarify the relations between morphometry and stratification in Italian lakes, we used a linear regression (Ambrosetti et al. 1996) to analyse the statistical dependence of the depth of the thermocline on the moment during the season when it develops. In elongated lakes the thermocline deepens steadily at a faster rate than that of circular lakes, which are practically stable after the beginning of the summer; however, in both groups of lakes there is a positive relationship between the rate of thermocline deepening and lake area.

\subsubsection{Heat content}

Without going into details of the evaluation of the individual energy components which make up the heat budget of a lake (there is extensive literature on the subject), we shall consider only the component which summarises them, i.e. the heat content of the lake. In particular we shall look at those aspects which periodically, or contemporaneously, affect the quantity of heat present in the water mass, and consequently the internal hydrodynamics of a lake and, in short, its renewal time.

Michalsky \& Lemmin (1995), and after them other researchers, established that the thermocline does not constitute an insurmountable barrier to the downward flux of heat; on the contrary, below the thermocline there are considerable water movements (shears, internal waves, density currents, etc.) even at very deep levels, with an intensity varying from lake to lake.

We arrived at the same conclusion (Ambrosetti \& Barbanti 2001), analysing the heat distribution over the annual cycle along the water column in 31 Italian lakes with maximum depths ranging from a few metres to more than $400 \mathrm{~m}$, and determining the percentage of total heat exchanged at various depths. Thus, the water layer involved in a 90\% energy exchange has in deep lakes a thickness of around an eighth of their maximum depth, whereas in shallow lakes this layer may be as much as four-fifths of the maximum depth (Fig. 1). In addition, the mean depth of the thermocline in the same lakes during July-August coincides almost exactly with a heat exchange depth of $90 \%$ in the shallow lakes, 50$60 \%$ in lakes of between 60 and $270 \mathrm{~m}$ depth, and below $50 \%$ in lakes deeper than $300 \mathrm{~m}$. Therefore, in lakes deeper than $100 \mathrm{~m}$, more than half of the heat exchange occurs below the thermocline, confirming that the ther- 


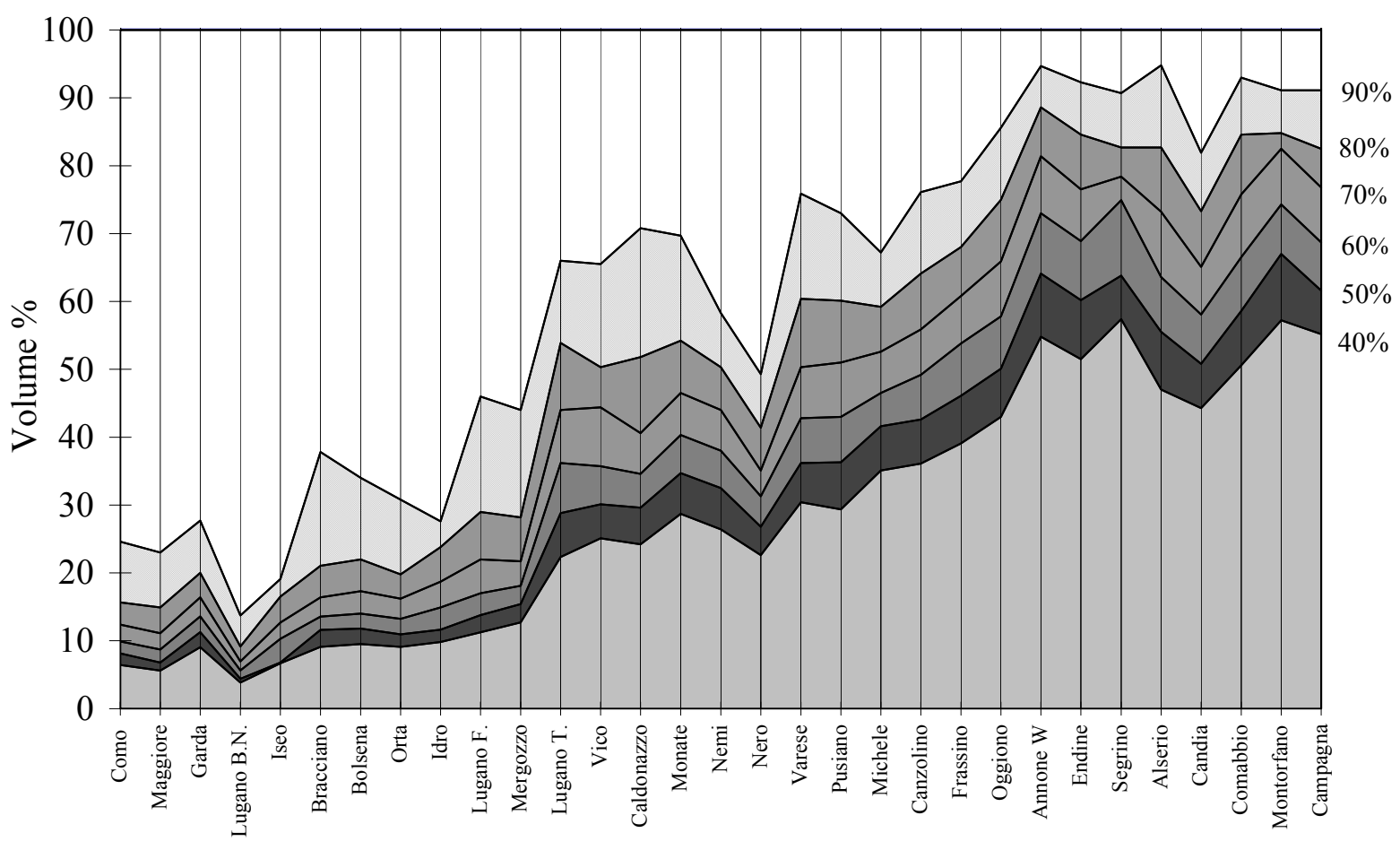

Fig. 2. Relationship between annual heat exchange percentage (40 to 90\%) and volume percentage of lake water involved. The lakes are in decreasing order of maximum depth.

mocline does not represent an absolute thermal barrier, and that the quantities of energy in play affect a layer which in deep lakes is 3-4 times the thickness of the epilimnion. This means that even during the most pronounced stratification phase, some of the heat present in the lake may go beyond the thermocline, although it cannot completely homogenise the layers above the hypolimnion.

The water volumes involved in these energy exchanges and thus potentially in the water renewal are shown in figure 2, where the 31 Italian lakes are given in decreasing order of maximum depth on the x-axis, and the water volumes are expressed according to the percentage of the whole lake volume (y-axis).

In the deepest Italian Lake Como, the water mass involved in the almost complete heat exchange (90\%) is only $1 / 4$ of its volume, while in the shallowest lakes almost the whole volume of the lake is involved. However, there are certain anomalies which can be explained only by taking into account the peculiarities of each lake, particularly as regards their hydrology.

The depth involved in the movements responsible for heat transport to the deep layers can be defined exactly by a comparison between the coefficients of vertical turbulent diffusion $\left(\mathrm{K}_{\mathrm{z}}\right)$ and of the Brunt-Väisälä frequency $\left(\mathrm{N}^{2}\right)$, the latter being an index of floating. Thus, in Lago Maggiore between April and August, the dominance of $\mathrm{K}_{\mathrm{z}}$ over $\mathrm{N}^{2}$ ends at a depth of around 150 $\mathrm{m}$ (Fig. 3), which means that on average the wind-in- duced vertical mixing is confined to this level in summer. The corresponding values in the other subalpine lakes, obtained using the same procedure, are: $180 \mathrm{~m}$ in L.Garda $\left(\mathrm{z}_{\max }=350 \mathrm{~m}\right) ; 150 \mathrm{~m}$ in L.Como $\left(\mathrm{z}_{\max }=410\right.$ $\mathrm{m}) ; 100 \mathrm{~m}$ in L. Iseo $\left(\mathrm{z}_{\max }=258 \mathrm{~m}\right) ; 75 \mathrm{~m}$ in L. Orta $\left(z_{\max }=143 \mathrm{~m}\right)$. The value for Lake Geneva, in contrast, is below $90 \mathrm{~m}$ (Michalsky \& Lemmin 1995).

This procedure may be used to identify in each lake the limit of separation between the "superficial" and the "deep" hypolimnion. The heat exchanged during the year in the upper layer has been quantified as $96-97 \%$ of the total exchange, while only the remaining $2-4 \%$ of the heat is able to reach the deepest part of the lake.

Nevertheless, if our aim is to define the thickness of the mixed layer, this subdivision within the hypolimnion has no importance, as this layer is limited towards the bottom of the thermocline. The input of heat at the lowest levels is, however, proof that a process of heat transport to the deep layers is taking place, and the outcome of this process will lead to the deepening of the thermocline and possibly to a full circulation.

The dynamic conditions in the deep hypolimnion of Lago Maggiore, as in the other large, deep subalpine lakes, are as we have seen largely dependant on the processes of turbulent diffusion in the overlying layer, at least for the whole seasonal phase dominated by thermal stratification and as long as there are no exceptional hydrological events (Barbanti \& Ambrosetti 1990; Ambrosetti et al. 1982). All the same, the periods 


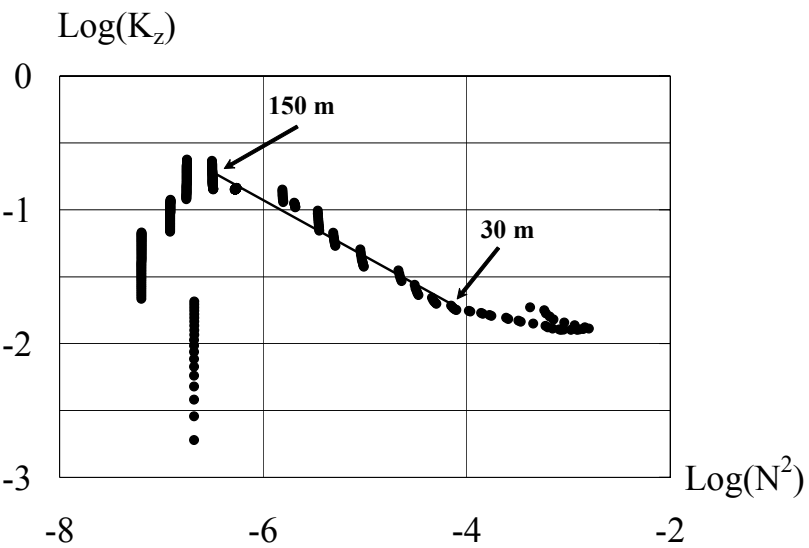

Fig. 3. Logarithm of the vertical mixing coefficient $\left(\mathrm{K}_{\mathrm{z}}\right)$ vs that of the Brunt- Väisälä frequency $\left(\mathrm{N}^{2}\right)$ in Lago Maggiore for the multiannual warming period from April to August.

between March and May and September-October are the most favourable for the accumulation of heat in the deep layers. In the first period, between the end of the limnological winter and the beginning of the summer stratification, the vertical distribution of temperature is not entirely stabilised, and there may be an input of very cold, dense water from the tributaries (following the snowmelt); proof of this is provided by the fact that in these two months the dissolved oxygen content reaches its maximum annual concentration on the bottom (Barbanti \&Ambrosetti 1985). The second favourable moment is when the sinking of the thermocline coincides with a reduction of the heat gradient, and not infrequently also with the heavy autumn rains, which increases the volume of the rivers; the concentration of bottom oxygen at this moment decreases due to the quantity of organic material transported to these depths.

\subsubsection{Thermal de-stratification}

In temperate lakes such as those in Italy the destratification process, dominated by convective motions, begins in autumn with the first major surface cooling and when the heat budget of the water mass becomes negative, i.e. the quantity of heat absorbed by the lake is less than that lost via its surface. This is the start of the progressive cooling of the epilimnion accompanied by its continuous deepening. Without entering into details of the process, we may say that this considerable work is performed by the turbulent kinetic energy developing in the upper layers, with the convective motions tending to affect an increasingly thick layer. The driving force of this mechanism derives partly from the potential energy present in the lake, which however decreases at a rate directly proportional to the loss of heat at the surface, and partly from wind stress to the level of the thermocline, with an amount of energy which varies in relation to the intensity of the wind.

On the basis of their seasonal thermal variations, Hutchinson (1957) classified lakes according to the number of vertical circulations which can occur during the annual cycle, i.e. when conditions of isothermia are reached on the whole column. Lakes can in this way be classed as amictic, cold monomictic, dimictic, warm monomictic, and polymictic. Actually, some deep basins can circulate completely only when the meteorological conditions are particularly favourable (strong winds and very low atmospheric temperatures); more often, as we have seen, isothermia involves only a part of the water mass (holo-oligomictic lakes).

For warm monomictic lakes, the category that includes the deepest Italian lakes, the maximum depth reached by vertical mixing can be estimated from the quantity of heat present in the water mass at the time of the limnological winter, and especially from our knowledge of its distribution along the vertical; in contrast, this estimate can be made in cold monomictic lakes in the limnological summer, while in dimictic lakes the estimate has to be made during the two transitional periods. Although Hutchinson's classification is widely accepted and includes almost all lakes, meteo-climatic, morphological, hydrological and chemical peculiarities of individual lakes may introduce variants into the standard classification of vertical mixing.

\subsubsection{An example of a dimictic lake: Lake Baikal}

Lake Baikal, the deepest body of fresh water in the world $\left(\mathrm{z}_{\max }=1632 \mathrm{~m}\right)$ and the one with the largest volume, is a dimictic lake by virtue of its location in the northern temperate zone. However, Weiss et al. (1991) point out that while it is commonly believed that deep lakes with surface temperatures which pass through the $4{ }^{\circ} \mathrm{C}$ temperature of maximum density twice a year turn over in autumn and in spring, this is not in fact the case, in so far as the temperature of maximum density decreases with increasing pressure at a rate of around $0.0021{ }^{\circ} \mathrm{C} \mathrm{bar}^{-1}$. So the water at the surface at $4{ }^{\circ} \mathrm{C}$ is at maximum density only at normal pressure, but is less dense than slightly colder waters at depth, and thus can- 


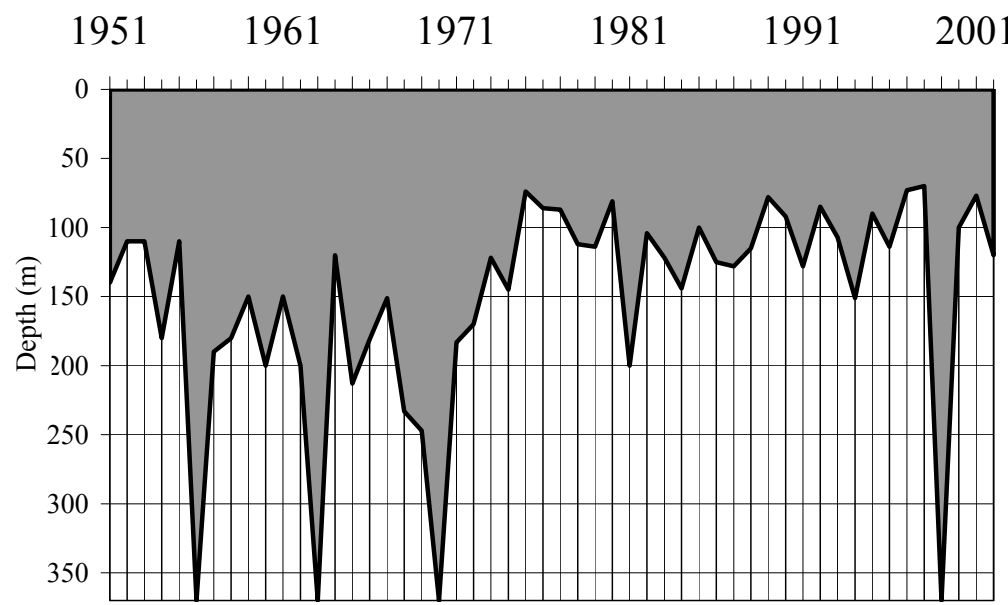

Fig. 4. Depths of vertical mixing of Lago Maggiore waters at the end of the limnological winter, 1951-2002.

not enter into free circulation with it. Since the maximum density of the underlying layers varies continually with depth, an additional physical mechanism is required to allow the displacement of deeper, colder water. According to the authors, deep convection in this lake occurs only locally and episodically as a result of a conditional instability, the so-called "thermobaric" instability, which depends on the combined effects of temperature and pressure on water density. Only in this case will deep water renewal be possible, by exchange with the surface water, by the process they call "ventilation".

Another study on Lake Baikal was performed by Killworth et al. (1996), who analysed temperature, dissolved oxygen, nutrients and CFCs, concluding that deep ventilation is produced by the differential compressibility of the water, and in particular that renewal events are governed by the "thermobaric" instability, in which particles of water sink towards the bottom, with the consequent displacement of colder water towards the upper layers. The authors also define three convective regimes along the water column: the upper regime, which lies above the thermobaric compensation depth, the middle regime where convection is governed by conditional instability at the thermobaric compensation depth, and lastly the lower layer close to the bottom, which represents the newer deep water.

\subsubsection{An example of a holo-oligomictic lake: Lago Maggiore}

Due to their location in the temperate zone, the large, deep lakes in the pre-Alpine areas to the south and north of the Alps are counted as warm monomictic lakes. This means that, in theory, a complete vertical mixing occurs only once a year, at the end of the limnological winter, i.e. around February-early March.

However, due to the great depth of these lakes, a complete vertical homogenisation of their water, reach- ing the bottom before the new process of thermal stratification begins at the surface, does not occur every year, so that it is more correct to class these lakes as holo-oligomictic (Ambrosetti \& Barbanti 1997).

This aspect of Lago Maggiore has been studied since the $50 \mathrm{~s}$, and it has been observed that a complete homogenisation of its water, i.e. to the maximum depth, occurs only in the case of particularly cold, windy winters: a situation which appears to be becoming more the exception than the rule. The winter mixing depths of the water in Lago Maggiore have been evaluated yearly through examination of vertical profiles of temperature, dissolved oxygen and other solutes, as well as by applying a predictive model which takes account of the meteorological conditions in the months before the onset of the limnological winter. This study revealed (Fig. 4) that the 7-year cycles recorded up to 1970 were followed by a period of 28 years (until 1999) during which the winter mixed layer only once (1981) reached a depth of $200 \mathrm{~m}$, with still shallower depths (between 50 and $150 \mathrm{~m}$ ) being reached in the other years. The complete circulation of 1999 occurred as a result of a double mechanism, i.e. with the concomitant action of convective motions to a depth of $200 \mathrm{~m}$, and the penetration of colder and more oxygenated waters of outside provenance in the layers below this level.

A similar situation of oligo-holomixis also occurred in Lake Orta $\left(\mathrm{z}_{\max }=143 \mathrm{~m}\right)$, where only 8 complete circulations, at intervals of up to 4 years, were recorded over 19 years (from 1984 to 2002); the greater mixing frequency than that observed in Lago Maggiore is clearly the result of its shallower depth. Similar late winter hydrodynamics are also found in the other lakes at the southern edge of the Alps, such as Como, Garda and Iseo (Ambrosetti et al. 1983; Ambrosetti \& Barbanti 1992; Salmaso 1997 ), and in many other lakes north of the Alps, such as Lake Geneva (Blanc et al. 1989, Meybeck et al. 1991) and Lake Constance (Heinz et al. 1990). 


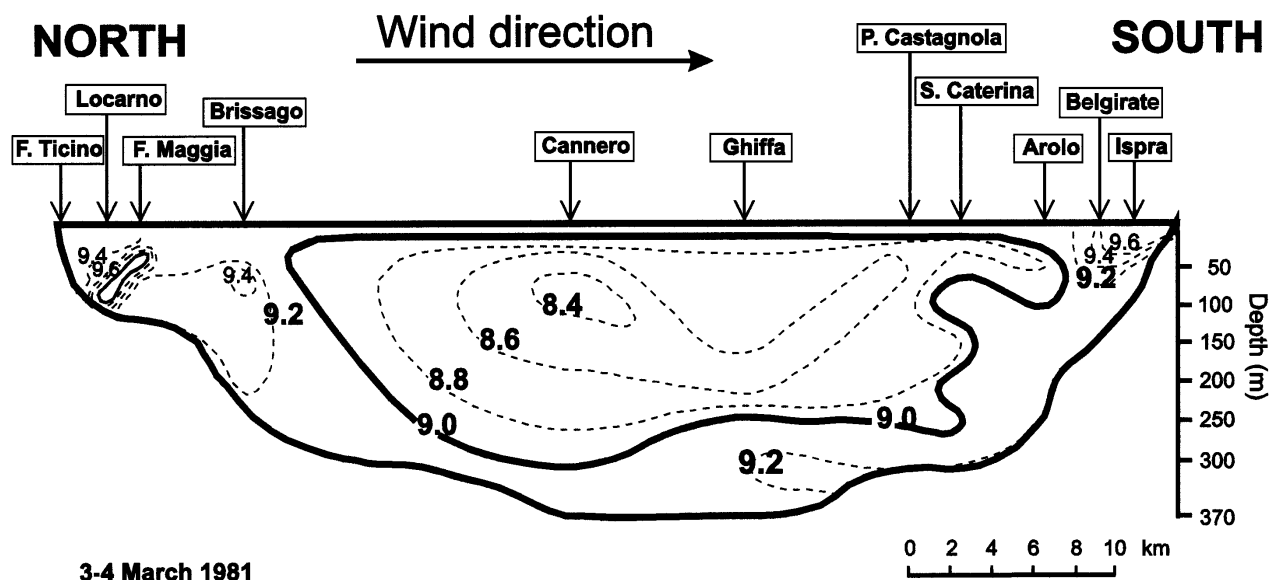

Fig. 5. Distribution of the concentration of oxygen in the whole Lago Maggiore basin.

It is therefore clear that this situation of holo-oligomixis in deep lakes must be kept in mind when evaluating their water renewal, as actual residence times are in this way considerably lengthened.

\subsection{Wind energy}

Wind stress and intensity on the lake surface depend on a number of other factors, such as the stability of the atmospheric layer immediately above the water body, variability in wind speed, fetch, the direction of the wind as compared to the lake's morphology, the degree of roughness of the lake surface, and the extent of the dissipation of wave energy on the shore.

It will be readily appreciated that the exchange of mechanical energy is anything but easy to define, and even less easy to evaluate in quantitative terms. Various modelling approaches have been proposed, with more or less satisfactory results, but the major problem, as yet unsolved, consists in establishing the form in which the energy transfer takes place, i.e. what proportion of the wind's work is transferred as kinetic energy to the different kinds of movement triggered in the water: waves, currents, turbulence, or surface and internal seiches. Consequently it is not surprising that exchanges of mechanical energy from the atmosphere to the lake's surface, and from the surface to the deep layers, are still described with reference to empirical or semi-empirical relations, which are often over-simplified and difficult to verify.

For example, by analysing the space-time variations in concentrations of dissolved oxygen in the hypolimnion of Lago Maggiore, Ambrosetti et al. (1982) were able to verify the presence of mechanisms different from the normal convection process but which were nevertheless able to re-oxygenate the deepest layers after the summer stagnation. One of these is the socalled "conveyor-belt" circulation, which functions synergically with other hydrodynamic mechanisms to set up in the lake a typical structure in which the deep water presents physical, chemical and biological characteristics very similar to those of the surface water, while the characteristics of the intermediate layer are quite different. This situation is caused by the wind, which in particular conditions of intensity and direction causes the surface water to drift rather than mix; by driving the surface water to the leeward end of the lake, it forces the water to sink, and, by continuity and compensation, to flow on the bottom in the opposite direction to the windward end, where it comes to the surface again (Fig. 5). The result is the characteristic conveyor belt circulation (Ambrosetti et al. 1982), also recorded in March 1981 by Sossau \& Pechlaner (1988) in the Traunsee (Austria), a lake of a depth of $189 \mathrm{~m}$.

The oxygenation, even partial, of the deep layers caused by these mechanisms can also compensate for the continuation of vertical circulations with oligomictic characteristics over several consecutive seasons (as occurred in Lago Maggiore from 1970 to 1998), preventing the deep waters from degenerating into a state of possible meromixis.

One of the most important responses of a thermally stratified lake to the episodic action of the wind is also the triggering of internal seiches, i.e. a series of oscillations developing at thermocline level and decreasing in amplitude on cessation of the triggering factor. Associated with these oscillations are large, persistent displacements of water masses that generate fluxes of shear and turbulent currents, which contribute to both mixing and dispersion.

As Imberger (1994) points out, the importance of the internal waves generated by the wind is that they spread kinetic energy over great distances, from the source to the point at which they are dissipated. Recent studies reveal that most of their energy is accumulated along the lake shore, where they also contribute significantly to changes in the shoreline, and where turbulent mixing and the re-suspension of bottom material occur (Munnick et al. 1992; Gloor et al. 1994). 
Turbulent mixing at the edge of the lake may also derive from the internal waves breaking close to the bottom and by the velocity of seiche currents above the hydraulically rough lake bottom (Garret \& Gilert 1988; Ivey \& Nokes 1989; Garret et al. 1993). But turbulent mixing also sets up horizontal intrusions of water of intermediate density into the lake (Imberger \& Patterson 1989). If the horizontal and vertical translocation of water masses and the seiche-born water mixing involve a relatively large portion of the lake, internal seiche activity can be an important factor also at the water-sediment interface, influenced by nutrient transport and the distribution of plankton and fish (Imboden et al. 1983; Gaedke \& Schimnele 1981; Leavy et al. 1991).

Using some observations on the space-time distribution of temperature and dissolved oxygen in Lake Kinneret $\left(\mathrm{z}_{\max }=42 \mathrm{~m}\right)$, Ostrovsky et al. (1996) arrived at a detailed picture of the mixing of the water mass and its movements deriving from the presence of internal seiches. Their data do not offer any direct evidence of the water movements (no current measurements were performed), but it is highly likely that the two phenomena (movements and seiches) are closely linked. Working on the same lake, Nishri et al. (2000) found that during the summer stratification the hypolimnion consisted of two layers, a turbulent benthic boundary layer, and the other overlying it. The whole epilimnetic mass moved in response to vertical mode one seiching of the metalimnion, and the movement was more accentuated along the edge of the lake due to shoaling, which caused the breaking of internal waves. The motion associated with these phenomena induced the formation of a wellmixed layer close to the bottom, with significant consequences for the exchange of mechanical energy and for the scale of biogeochemical processes.

\subsection{Energy advected from the tributaries}

Inflowing waters normally have physical and chemical characteristics which are different from those of the lake, particularly as regards their solute concentrations, so that their intrusion into the lake may result in the riverine water flowing on the surface (overflow), in depth (underflow), or at an intermediate level (interflow). Here we are not so much concerned with the inevitable load of suspended or dissolved material conveyed to the lake, as with the input of kinetic and potential energy which is linked to the difference in thermal and/or chemical density between the riverine and the ambient water. When large water masses flow into the lake from the watershed, the tributaries with the greatest volumes can produce a plume of current which is identifiable for a considerable distance, and operating at various levels may even reach the deepest layers, causing high turbulence and facilitating mixing. Such plumes have been observed in lakes Maggiore, Iseo and Como, where their space-time distribution has been monitored and some parameters measured, such as temperature and dissolved oxygen concentration, incontrovertible evidence of their riverine origin (Barbanti \& Ambrosetti 1989). These flood events may be negligible in lakes where the surface area-watershed ratio is low (e.g. lakes Bolsena, Bracciano, Vico, Nemi), at least as regards their incidence on deep water renewal times, but are quite frequent and of some importance in others, such as Maggiore and Como.

During the flood in Lago Maggiore in August 1978, a limnological survey was immediately undertaken, with ecobathymetric probes, current measurements with drift cruises da deriva, vertical water temperature measurements, and chemical and biological analyses on samples taken at various depths in several stations. This survey showed how the distribution of inflowing waters took place at two preferential intrusion levels (Ambrosetti et al. 1980). The main flow, with an upper limit at a depth of 5-6 metres, was identifiable for several kilometres beyond the river mouth and was particularly evident in the Pallanza basin; as it moved further away from the inflow point, however, the turbid water spread into some well defined but more limited areas, and gradually sank. A second inflow level was observed in the deepest layers of the main basin (below $300 \mathrm{~m}$ ), where it introduced relatively high temperatures and in particular the presence of turbid water. Clearly this double intrusion was caused by the different densities of the water of each tributary, a result of their different temperatures and suspended loads.

Another memorable hydro-meteorological event occurred in Lago Maggiore in the autumn of 1993, when once again an immediate limnological survey was initiated, followed by evaluation of the hydrological budget for the duration of the event. The high inflows of water to the lake resulted in a marked reduction of the theoretical renewal time, or, putting it another way, a marked acceleration of the water renewal: the mean theoretical time of 4 years in Lago Maggiore dropped, in the period from 30 September to 12 October, to around 8 months. However, the riverine intrusions affected almost exclusively the top 100 metres of lake water, as is shown by the heat flux trends in the water column, so that the real renewal time must be applied to this hydrodynamic situation. The autumn 1993 flood, with its load of potential energy, also caused heat exchanges in the water mass which were anything but negligible, with evident changes in the vertical thermal structure of the lake. It was calculated that just in the 24 hours of 30 September 1993 the advected energy reached values around 3 times higher than those deriving from solar radiation on a cloudless summer day.

Lakes at the edge of high mountain ranges may receive an input of cold riverine waters originating from the spring snow- and ice-melt, which on their way from the point of inflow to the point of outflow sink to the maximum depths. There are many instances of such episodes; one of them, whose evolution is illustrated in 
18 April 1985

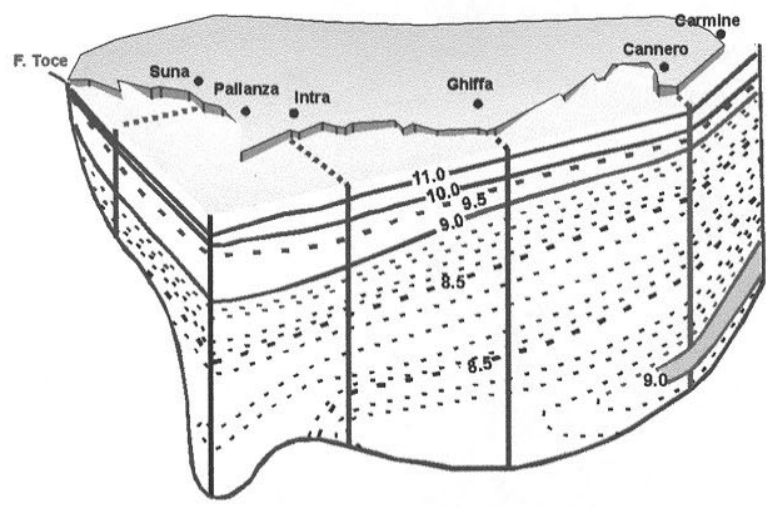

24 April 1985

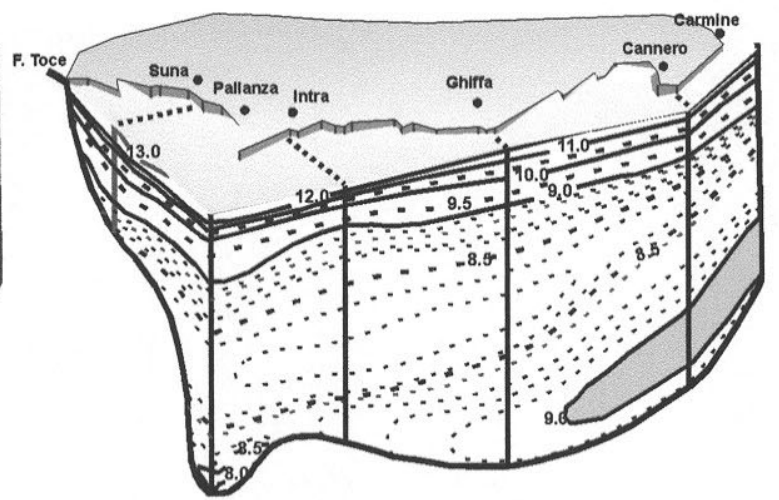

Fig. 6. Example of the sinking of riverine water masses in the central part of Lago Maggiore.

figure 6, developed in Lago Maggiore between 18 and 24 April 1985. This was a "crossing flow", which emerged clearly both from the vertical temperature distribution and from the $\mathrm{O}_{2}$ concentrations; the figure shows the central, deepest part of the lake, which is already quite far from the inflow point of the tributaries.

This is also a demonstration of the ecological impact of watershed altitude on the lake ecosystem. The accumulation of snowy precipitation during the winter gives rise at the thaw to intrusions of masses of very dense cold water in the lake, which sink to the deepest levels and often bring a high oxygen contribution. Phenomena of this kind were recorded in Lago Maggiore in the years from 1984 to 1986 and in 1991, and also in lakes Como and Iseo. The mechanisms were also observed in Lake Geneva from 1972 to 1980 by Meybek et al. (1991), who ascribed them to other processes in addition to the intrusion of denser water, such as the accumulation of turbidity in the water, or wind storms; and though the quantity of water arriving in the lake is generally quite small (less than $1 \%$ of the total volume of the basin), they ensure adequate oxygenation of the deepest levels, even when the vertical mixing does not reach the bottom.

Working on Lake Baikal, Hohmann et al. (1997) also identified two mechanisms of deep water mixing, based on nearly 600 CTD profiles taken between 1993 and 1995. In spring (April-May), cold and relatively saline water from the Selenga, the major inflow to the lake, forms a density plume that reaches the bottom of the central basin, the deepest of the lake's basins, to which it transports about $125 \mathrm{~km}^{3}$ of water per year. There are, however, also indications that parts of the Selenga plunge to the deep part of the southern basin. At the Academician Ridge, the sill separating the cold, saline water of the central basin from the warmer, slightly less saline water of the southern basin, horizontal mixing takes place, resulting in a water mass that can sink on the other side of the sill deep into the northern basin, while in the central basin the water mass remains at an intermediate depth. The authors did not find any indication of wind-induced thermobaric instability (the process discussed above), which means that, as regards vertical mixing, hydrology prevails over anemology, at least at certain times of year.

Finally, and again in Lake Baikal, Ravens et al. (2000) analysed vertical temperature microstructure profiles, monthly CTD profiles, and records of nearbottom currents, concluding that the water column below $250 \mathrm{~m}$ is extremely weakly, but permanently, stratified. Despite the fact that this water mass of more than $1000 \mathrm{~m}$ thickness is relatively stagnant, its "age" (time since its last contact with the atmosphere) is only slightly more than a decade. This can only indicate the existence of large-scale advective exchange; the stratified deep water is thus subject to the combined action of intrusions of external water masses (from the tributaries), and of small-scale turbulence.

\section{EFFECT OF ONGOING CLIMATE CHANGES}

The long historic series of experimental limnological data (thermal in particular) available to us, such as those we used to elaborate the sequence of the depths reached by the maximum vertical late winter mixing in Lago Maggiore, reveal the fact that marked climate changes are in progress. Though these changes are irrelevant to some situations, like the sequence just cited, this is not true for other aspects of lake hydrodynamics, for instance, those closely related to water renewal times.

The dynamics of global climate change may not be wholly understood, but it is undeniable that the atmospheric temperature is increasing; and the great masses of lake water too are experiencing changes in the ratios between the various forms of exchanged energy, whether at the water-atmosphere interface or through the inflow from the tributaries. This situation has reper- 
cussions on the whole water column, with variations in some aspects of internal hydrodynamics, to the point that changes in water quality are also being seen.

Hondzo \& Heinz (1991), for example, applied a model to three lakes in the centre-north of the USA (Calhon, Elmo and Holland), to test (among other things) the impact of global warming on them. Their results showed that there was a considerable increase in the temperature of the epilimnion, a greater loss of energy through evaporation, and an earlier summer stratification, than in the past. They did not find any notable impact on the temperature of the hypolimnion, as the spring vertical mixing events had thermally homogenised the whole column (the maximum depth of these lakes is $42 \mathrm{~m}$ ).

Italian lakes, too, especially the deepest of them, have in recent years shown a marked increase in the heat of the whole water mass, with consequent evident changes in their vertical thermal structure. In particular, there has been a reduction in the depths reached by the winter mixing, i.e. the moment when the so-called "new water mass" is formed; there have also been variations in the processes of turbulent convection, linked both to meteo-climatic changes and to inflows of cold oxygenated water, or warmer but very dense waters, from the tributaries, all of which may also involve profound changes in the thermal structures of the hypolimnion.

Studies on Lago Maggiore revealed a marked increase in summer energy content on the whole lake volume of around $850 \mathrm{MJ} \mathrm{m}^{-2}$ from 1963 to 1998; in Lake Orta, again in summer, the increase from 1981 to 1999 was almost $600 \mathrm{MJ} \mathrm{m}^{-2}$. This distinct increase in heat has determined in both lakes a general lowering of the depth of the layer involved in the heat exchange. For instance, the $90 \%$ exchange depth in Lago Maggiore has over the last 40 years experienced a mean annual deepening of $0.130 \mathrm{~m}$, from 37 metres in 1963 to 48 metres in 1999. The deepening in Lake Orta between 1984 and 1999 was even more striking: $2.22 \mathrm{~m}$, an average of $0.138 \mathrm{~m}$ per year. These processes obviously also involve an increase in the thickness of the epilimnion (Ambrosetti \& Barbanti 2002), increasing the availability of a greater volume of water for the summer renewal, if we adhere to the hypothesis that only the water in the surface layer takes part in the renewal.

The heating of the $0-50 \mathrm{~m}$ layers does not emerge clearly from the historical series of temperature data, as it is partly masked by the presence of seasonal cycles (Fig. 7A), though there is a trend in the direction of a general increase. The effect of global warming is more noticeable in the deep hypolimnion, which is only slightly, if at all, affected by daily or seasonal thermal variations (Fig. 7B). In this way the deep layers contain a kind of "climatic memory", which reveals thermal variations on a relatively long time scale, comparable with that of the ongoing climatic changes, and its trend can yield information on events of particular intensity which have had a significant impact on the lake.
Figure 8 compares the climatic memory of lakes Maggiore, Garda and Orta (Ambrosetti \& Barbanti 1999, 2000 and 2001). From 1963 to 1998 the overall increase occurred at a similar rate in the three lakes, with a halt from 1982 to 1986 and with variations, both negative and positive and of varying dimensions, which appear at the same time in each basin. The most striking of these variations were the negative ones in 1981 and 1991, caused by exceptional meteorological and hydrological events on a regional scale involving the transport of surface water to the deep layers (Ambrosetti et al. 1982); the result was a marked decrease in the positive trend of the climatic memory, with a considerable reduction in the accumulation of energy.
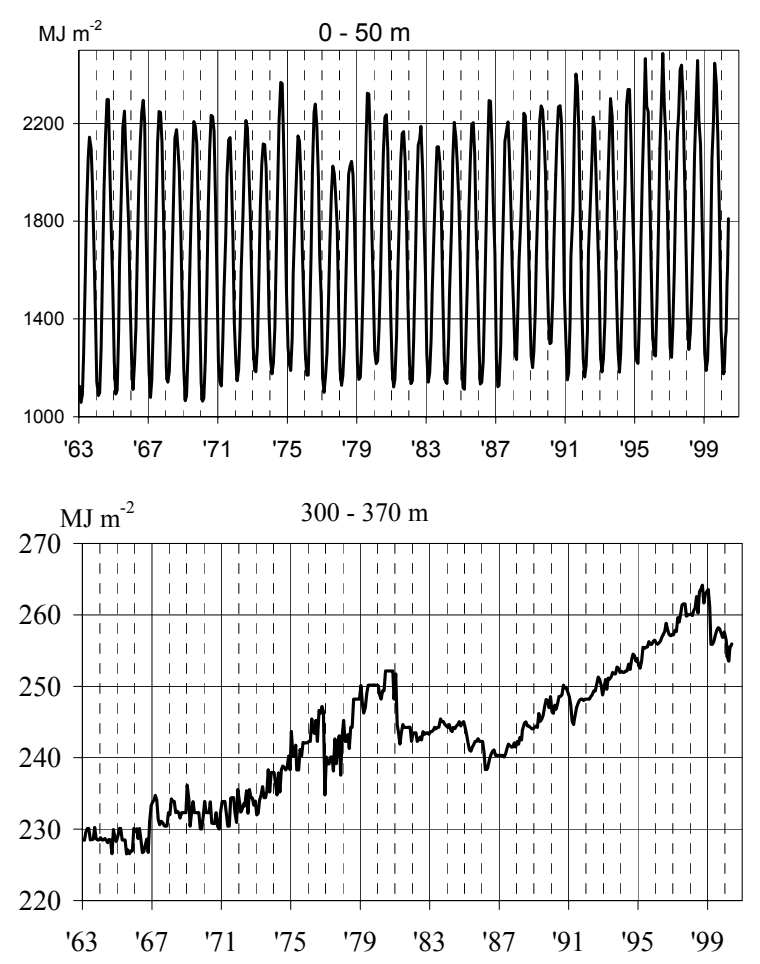

Fig. 7. Heat content in some layers of the Lago Maggiore water column.

However, while external events of this kind may be able to modify the direction of the trend, as things currently stand they cannot return the lake to the energy content situation of the earliest years of the period under consideration. For instance, at the end of winter 1999 Lago Maggiore displayed a value of $5.193 \mathrm{MJ} \mathrm{m}^{-2}$, equivalent to a mean temperature of $6,7-6,8^{\circ} \mathrm{C}$ on the whole column; a value higher by 630 and $840 \mathrm{MJ} \mathrm{m}^{-2}$ than in 1970 and 1963, corresponding to a mean temperature on the column of 5.8 and $6.0^{\circ} \mathrm{C}$. To produce the 1999 complete vertical mixing at $6.7^{\circ} \mathrm{C}, 10$ times more work was required than for the 1963 mixing, and without the possibility of re-establishing the initial thermal conditions, i.e. a mean temperature of $5.8^{\circ} \mathrm{C}$ on the column (Ambrosetti \& Barbanti 2000). 


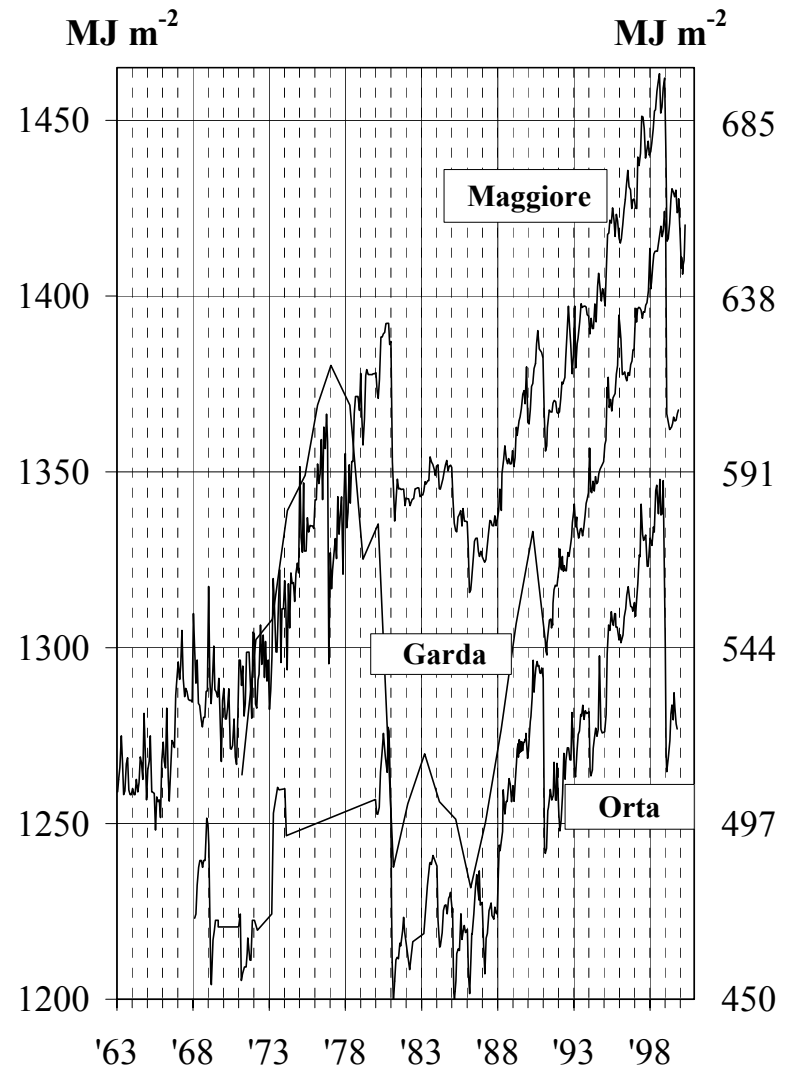

Fig. 8. Trend of climatic memory in lakes Maggiore, Garda and Orta, based on approximately fortnightly data. Orta values are shown on right y-axis.

Thus the complete circulation of water in deep lakes is destined to become more and more difficult to achieve in the future, with major repercussions for their hydrodynamics. With continually rising water temperatures, the variations in density between layers of equal thermal difference are always higher than when the temperature is close to $4{ }^{\circ} \mathrm{C}$.

To sum up, the ongoing climate changes, the increase in temperature in particular, are having a double, and contrasting, impact on the renewal times of lake waters.

In summer, a possible increase in the thickness of the mixed layer accelerates the renewal time, as a greater volume of water is involved. In winter, on the other hand, the need for more mixing work to trigger a complete vertical mixing, or at any rate a deeper mixing, reduces the volume of the water mass involved in the renewal.

\section{LAKE BOLSENA}

Some comments must be made on Lake Bolsena, where this meeting is being held. We shall use the data provided by Bruni (1997, 1998, 2002), comparing them with the results of studies performed by the Istituto Italiano di Idrobiologia in the sixties. Table 1, which at the beginning of this contribution showed the theoretical renewal times of the major Italian lakes, indicated a renewal time for Bolsena of around 120 years. However, since 1960 the volume of the outflow (Marta) has decreased from $2.5 \mathrm{~m}^{3} \mathrm{~s}^{-1}$ to its present value of $1 \mathrm{~m}^{3} \mathrm{~s}^{-1}$, so that the theoretical renewal time is now around 300 years. The reasons for this decrease and the consequences for the water quality of Lake Bolsena are quite alarming and are discussed in detail by Bruni (2002).

Thermal measurements show that the total winter caloric content of the lake increased substantially (around 16\%) from 1969 to 1998 , with the mean temperature on the column rising from $7.44{ }^{\circ} \mathrm{C}$ to $8.4{ }^{\circ} \mathrm{C}$, i.e. an increase of around $1.0^{\circ} \mathrm{C}$, which is in agreement with the increase recorded in the large, deep lakes to the south of the Alps. The summer caloric content behaved similarly, with a much greater increase than in winter (34\%), while the caloric content of the deep hypolimnion below 75 metres, the layer containing the "climatic memory", rose by around 18\%.

Full circulation in Bolsena is therefore increasingly unlikely, for the same reasons as for the deep lakes south of the Alps. This can also been understood from the values of winter thermal stability; this parameter, defined as the work necessary to mix a thermally stratified lake to isothermia in adiabatic conditions, has increased over the period under consideration from $151 \mathrm{~J}$ $\mathrm{m}^{-2}$ to $589 \mathrm{~J} \mathrm{~m}^{-2}$. Its vertical distribution in Lake Bolsena, determined according to Walker's method (1974), is shown in figure 9, which compares the 1969 and 1998 values. In 1969 , the thermal stability at $-110 \mathrm{~m}$ had a maximum value of $0.27 \mathrm{~J} \mathrm{~m}^{-2}$, indicating that this level is the limit for vertical mixing. In contrast, the 1998 curve shows at all levels values higher than those of 1969 with a maximum $\left(0.57 \mathrm{~J} \mathrm{~m}^{-2}\right)$ at $-105 \mathrm{~m}$, a value more than twice that of 1969 , as well as conditions of marked stability starting from the layers nearest the surface. The implications of this are that a considerable increase in work will be required in the future if a complete mixing of the water is to be achieved.

\section{CONCLUSIONS}

All the results of studies of the exchange of caloric energy between the atmosphere and the lake water, and the exchange of mechanical energy with wind and inflows, show that the control of these is decisive for the hydrodynamic characteristics of the water mass of a lake. And the resulting thermal structures, which vary in time and space in relation to external conditions, are also extremely important for the chemistry and biology of each water body. Furthermore, the climate changes currently in progress are assuming the role of a "nerve centre" in lake management, and are altering the equilibriums of atmosphere-lake and river-lake, so that relations within the lake are being changed, with an impact not only on the lake ecosystem but also on the surrounding area, with in particular a worsening of extreme 
phenomena. The signs of these phenomena are already present and well-documented, even though they are still at a level which could be the result of the natural variability of the climate. The fact remains that if the drive towards upsetting the equilibrium of the atmosphere gains the upper hand, the results could be catastrophic.

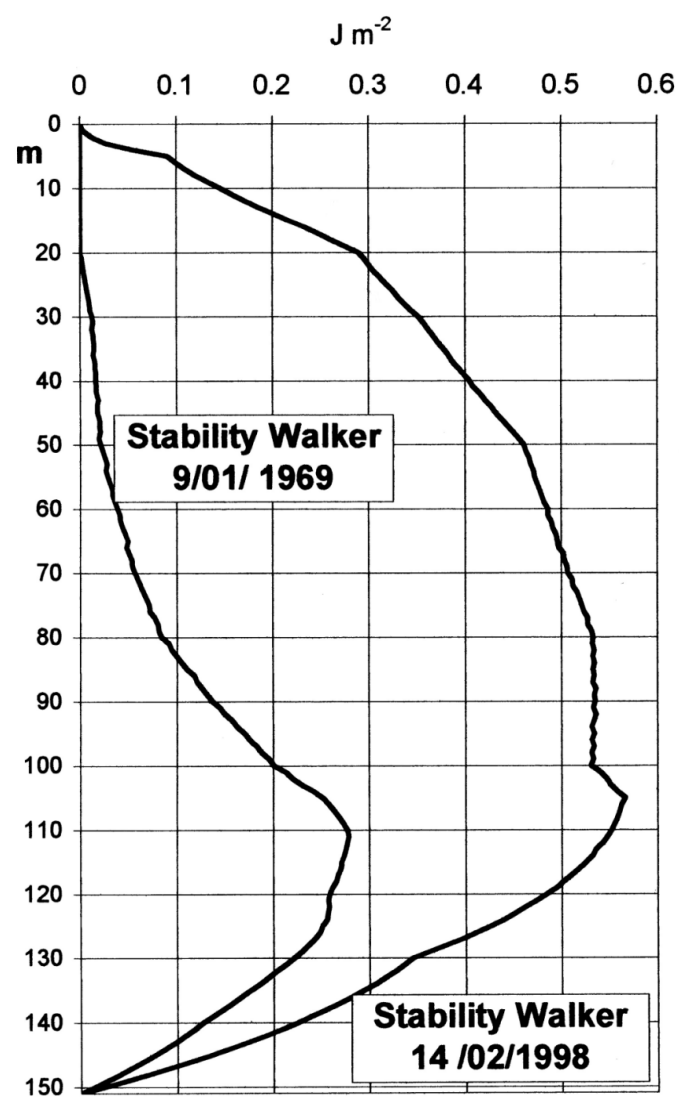

Fig. 9. Vertical profiles of thermal stability in Lake Bolsena in winter 1969 and 1998 sensu Walker.

However, to return to the main topic of this contribution, lake water renewal times need to be measured with increasing precision, especially in relation to their undisputed impact on many of the chemical and biological processes involved in the ecosystem. It is nonetheless difficult to say what general line should be followed to achieve these results, due to the extreme complexity of the physical compartment, with a great many variables and synergisms which can be hard to interpret. Processes are involved which are not always entirely clear, even to modern limnology, and besides each lake presents its own specific characteristics, with the prevalence of certain phenomena, and it is not always easy to identify them. These objective difficulties should not discourage us from the urgent task of extending our knowledge of the dynamics governing the complex lake ecosystem, with the aid of the increasingly sophisticated instruments which modern technology can offer to the science of limnology.

\section{REFERENCES}

Ambrosetti, W. \& L. Barbanti. 2002. Physical limnology of Italian lakes. 1 Relationship between morphometry and heat content. J. Limnol., 61(2): 147-157.

Ambrosetti, W. \& L. Barbanti.2002. Physical limnology of Italian lakes. 2. Relationships between morphometric parameters, stability and Birgean work. J. Limnol., 61(2): 159-167.

Ambrosetti, W. \& L. Barbanti. 1992. Evidenza di situazioni olo-oligomittiche nel Lago d'Orta. Atti del IX Congresso A.I.O.L.: 433-444.

Ambrosetti, W.\& L. Barbanti. 1999. Deep water warming in lakes: an indicator of climate change. J. Limnol., 58(1): 19.

Ambrosetti, W. \& L. Barbanti. 2000. Riscaldamento delle acque profonde nei laghi italiani: un indicatore di cambiamenti climatici. Acqua \& Aria, 4: 65-72.

Ambrosetti, W., L. Barbanti \& L. Pompilio.1996. Morphometry and thermal stratification in Italian lakes. 3. Dynamic of the deepening of thermocline. Mem. Ist. ital. idrobiol., 54: 43-50.

Ambrosetti, W. \& L. Barbanti. 1988. Recenti indagini di limnologia fisica sul Lago Maggiore. Acqua \& Aria, 1: 27 38.

Ambrosetti, W., L. Barbanti \& R. Mosello. 1982. Unusual deep mixing of Lago Maggiore during the winter 19801981. Geogr. Fis. Dinam. Quat., 5: 183-191.

Ambrosetti, W., L. Barbanti, R. Mosello, A. Rolla \&D. Ruggiu. 1983. Mescolamento, caratteristiche chimiche, fitoplancton e situazione trofica nei laghi profondi sudalpini. C.N.R., P.F. Promozione della qualità dell'ambiente, $\mathrm{AQ} / 2 / 20: 151 \mathrm{pp}$.

Ambrosetti, W., L. Barbanti, R. de Bernardi \& V. Libera. 1980. Alcune risposte ad un envento meteorlogico eccezionale : il nubifragio del 7 Agosto 1978 nel bacino del Lago Maggiore. Atti $3^{\circ}$ Congresso A.I.O.L.: 389-406.

Barbanti., L., L. Pompilio \& W. Ambrosetti. 1996. Morphometry and thermal stratification in Italian lakes. 2. The "Depth Ratio" as a predictive index of thermal structures. Mem. Ist. ital. Idrobiol., 54: 31-42.

Barbanti, L., L. Pompilio \& W. Ambrosetti.1995. La piena dell'Autunno 1993 nel Lago Maggiore: ripercussioni sulle sue caratteristiche fisiche. Documenta. Ist. ital. Idrobiol., 50: $56 \mathrm{pp}$.

Biffi, F. 1963. Determinazione del fattore tempo come caratteristica del potere di autodepurazione del Lago d'Orta in relazione ad un inquinamento costante. Atti Ist. Ven. Sci. Let. Arti. 121: 131-136.

Blanc, P., C. Corvi \& F. Rapin. 1989. Evolution physicochimique des eaux du Leman. Rapp. Comm int. prot. eaux Leman contre pollut. , Campagne 1988: 23-43.

Bruni, P. 2002. Il Lago di Bolsena. Associazione Lago di Bolsena. Il Giornale del lago $\mathrm{n}^{\circ} 13: 32 \mathrm{pp}$.

Bruni, P. 1998. Monitoraggio del Lago di Bolsena. Associazione Lago di Bolsena. Amm. Prov. Viterbo. Ass. all'Ambiente: $23 \mathrm{pp}$.

Carmach, E.C., R.C. Wiegand, R.J. Daley, C.B.J. Gray, S. Jasper \& C.H. Pharo. 1986. Mechanisms influencing the circulation and distribution of water mass in a medium residence-time lake. Limnol. Oceanogr., 31(2): 249-265.

Gaedke, D.E., \& M.Schimmele.1991. Internal seiches in Lake Costance: Influence on Plankton abundance at a fixed sampling site: J. Plankton Res., 13: 743-754

Garrett, C. \& D. Gilbert. 1988. Estimates of vertical mixing by internal wawes reflected off a sloping botton. In: J.J. Nihoul \& B.M. Jamart (Eds), Small scale turbulence and mixing in the ocean. Elsevier: 405-424.

Garrett, C, P. Mac Cready \& P. Rhines. 1993. Boundary mixing and arrested Ekman layers: Rotating stratified flow 
near a sloping boundary. Annu. Rev. Fluid. Mech., 25: 291-323.

Gloor, M., A. Wuest \& M.Munnich. 1994.Benthic boundary mixing and resuspension induced by internal seiches. Hydrobiologia, 284: 59-68.

Hamblin, P. F. 1982. On the free surface oscillations of Lake Ontario. Limnol. Oceanogr., 27(6): 1039-1049.

Heinz, G., J. Imberger \& M. Schimmele. 1990. Vertical mixing in Ueberlinger See, western part of Lake Constance. Aquatic Sciences, 52: 256-268.

Hollan, E. \& T.J. Simmons. 1978. Wind-induced changes of temperature and currents in lake Costance. Arch. Meteorol. Geophys. Biol. Ser. A 27: 333-373.

Hohmann,, R., R. Kipfer, F. Peeters, G. Piepke, D.M. Imboden \& M.N. Shimaraev. 1997. Processes of deep-water renewall in Lake Baikal. Limnol. Oceanogr., 42(5): 841855.

Hondzo, M. \& H.G Stefan. 1991. Three case studies of lake temperature and stratification response to warmer climate. Water Resour. Res., 27(8): 1837-1846.

Hutchinson, G.E. 1957. A treatise on limnology. Vol. 1. John Wiley and Sons, New York: 1015 pp.

Imberger, J. 1994. Transport processes in lakes: A review. In: R. Margalef (Ed.), Limnology now: A paradigm of planetary problems. Elsevier Science: 79-193

Imberger, J. \& J.C. Patterson. 1990. Physical limnology. Adv. Appl. Mech., 27: 303-475.

Imberger, J., Hebbert B. \& I. Loh. 1978. Dynamics of reservoir of of medium size. J. Hydraul. Div. AM. Soc. Civ. Eng., 104: 725-743.

Mortimer, C.H. 1974. Lake hydrodynamics. Mitt. Int. Ver. Theor. Angew. Limnol., 20: 124-197.

Imboden, D.U. Lemmin, T. Joller \& M. Schurten. 1983. Mixing processes in lakes: Mechanisms and ecological relevance. Schweiz. Z. Hydrol., 45: 11-44.

Ivey, G.N. \& R.I. Nokes. 1989. Vertical mixing due to the breaking of internal waves on sloping boundaries. J. Fluid Mech., 204: 479-500.

Killoworth, P.D., E.C. Carmack, R.F. Weiss \& R.Matear. 1996. Modeling deep-water renewal in Lake Baikal. Limnol. Oceanogr., 41: 1521-1538.

Levy, D.A., R.L. Johnson \& J.M. Hume. 1991. Shift in fish vertical distrbution in response to an internal seiches in a stratified lake. Limnol. Oceanogr., 36: 187-192

Meybeck, M., P. Blanc, A.E. Moulherac \& C. Corvi. 1991. Chemical evidence of water movements in the deepest part of Lake Leman (Lake Geneva). Aquatic Sciences, 53(4): 273-289.

Michalsky, J. \& U. Lemmin. 1995. Dynamics of vertical mixing in the hypolimnion of a deep lake: Lake Geneva. Limnol. Oceanogr., 40(4): 809-816.

Munnick, M., A. Wuest \& D.M. Imboden.1992. Observation of the second vertical mode of internal seiche in an alpine lake. Limnol. Oceanogr., 37: 1705-1719.

Nishri, A., J. Imberger, W. Eckert, I. Otrovsky \& Y Geifman. 2000. The physical regime and the respective biogeo- chemical processes in the lower water mass of Lake Kinneret. Limnol. Oceanogr., 45(4): 972-981.

Ostrovsky, I.D., Y.Z. Yacobi, P. Walline \& I. Kalikhman. 1996. Seiche-induced mixing: Its impact on lake productivity. Limnol. Oceanogr., 41: 323-332.

Piontelli, R. \& V. Tonolli. 1964. Il tempo di residenza delle acque lacustri in relazione ai fenomeni di arricchimento in sostanze immesse, con particolare riguardo al Lago Maggiore. Mem. Ist. ital. Idrobiol., 17: 247-266.

Pompilio, L., W. Ambrosetti \& L. Barbanti. 1996. Morphometry and thermal stratification in Italian lakes. 1. Predictive models. Mem. Ist. ital. Idrobiol., 54. 1-29.

Rainey, R.H. 1967. Estimation of detention period of a lake. Verh. int. Ver. Limnol., 155: 1242-1243.

Ravens, M.T., O. Kis \& A. Wüest.2000. Small-scale turbulence and vertical mixing in lake Baikal. Limnol. Oceanogr., 45(1): 159-173.

Rueda, F. J. 2001. A three-dimensional hydrodynamic and transport model for lake environments. Ph.D. Dissertation, University of California, Davis.

Rueda, F.J., S.G. Schladow \& S.O. Palmarsson. 2002. Basinscale internal wave dynamics during a winter cooling period in a large lake. Journal of Geophysical Research: (in press).

Salmaso, N., F. Decet, M.,Manfrin \& P. Cordella.1997 Ricerche limnologiche sul Lago di Garda (1991-1996). Documenta Ist. ital. idrobiol., 61: 173-199.

Smith, P. E. 1997. A three-dimensional, finite-difference model for estuarine circulation. Ph.D. Dissertation, University of California, Davis.

Sossau, C. \& R. Pechlaner. 1988. The regained,but hidden holomixis of the Austrian Lake Traunsee. Verh. int. Ver. Limnol., 23: 74-79.

Sundaram, T. R. \& R. G. Rehm. 1973, The seasonal thermal strcture of deep temperature lakes. Tellus, 25: 157-167.

Tucker, W.A. \& A.W. Green. 1977. A time dependent model of the lake-averaged vertical temperature distribution in lakes. Limnol. Oceanogr., 22: 687-699.

Vollenweider, R.A. 1964. Die Beziehung zwischen Einzugsgebiet und Seenhaushalt. Unpubl. Vortrag an der Deutschen Limnologentagung, Lunz.

Vollenweider, R.A. 1969. Möglichkeiten und Grenzen elementare Modellre der stoffbilanz von Seen. Arch. Hydrobiol., 66(1) : 1-36.

Vollenweider, R.A. 1975.Input-output model with special reference to the phosphorus loading concept in limnology. Z. Hydrobiol., 37: 53-84.

Weiss, R.F., E.C. Carmack \& V.M. Koropalov. 1991. Deep water renewal and biological production in Lake Baikal. Nature, 349: 665-669.

Welander, P. 1968 Theoretical forms for the vertical exchange coefficient in a stratified fluid with application to lakes and seas. Acta R. Soc. Sci. Litt. Gotheb. Geophys., 1: 1-26.

Wüest, A., D. M. Imboden \& M. Schurter. 1988. Origin and size of hypolimnic mixing in Urnersee, the southern basin of Vierwaldstättersee (Lake Lucerne). Schweiz. Z. Hydrol., 50: 40-70. 